\title{
Who Wants Enlargement of the EU? Support for Enlargement among Elites and Citizens in the European Union
}

\author{
SYLKE NISSEN* \\ University of Leipzig, Germany
}

\begin{abstract}
A collective European identity is often mentioned as important for the European Union's future. The article discusses common definitions of collective identity and proposes to add a utilitarian component to the concept. In this respect, political solidarity and, particularly, interest in and support for the coming Eastern enlargement are taken as an indicator of European identity. As a starting point for further discussion on the structure and necessity of European identity, the article examines enlargement support among political actors and citizens in EU countries and demonstrates that support for enlargement is distributed differently on these levels. It is argued that EU elite politics does little to promote the development of a collective European identity and might even get the European integration process into some difficulty.

Sociologický časopis/Czech Sociological Review, 2003, Vol. 39, No. 6: 757-772
\end{abstract}

\section{European identity and Eastern enlargement}

The current discussion on the future of Europe frequently mentions a European identity as a decisive prerequisite for the successful development of Project Europe. "The process of European integration proceeds while the common market is extended and political decision-making authority is transferred to the European level at an accelerating pace. More and more this process needs the integration of the citizens and a change of their identity towards Europe. ... Without this change of identity the European project is in danger of failure because of the lack of people's will for co-operation" [Münch 1999: 223, my translation]. The empirical basis for these kinds of normative demands remains unexamined.

On the other hand, a number of contributions to the debate state that a collective European identity already partially exists. But hints as to the grounds for this identity and its sustainability are usually missing. The European Commission, for instance, has surveys conducted twice a year in all member states of the EU. These polls include a question on whether the citizens see themselves as Europeans only,

\footnotetext{
* Direct all correspondence to: Dr. Sylke Nissen, Institute of Sociology, University of Leipzig, Beethovenstr. 15, D-04107 Leipzig, Germany, e-mail: nissen@rz.uni-leipzig.de

(C) Institute of Sociology, Academy of Sciences of the Czech Republic, Prague 2003
} 
or solely as members of their particular nation, or as both Europeans and French, Europeans and Britons, Europeans and Greeks, etc., at the same time. The Commission's Standard Eurobarometer takes the answers to this question, without any further analysis, as an expression of 'European and national identity' [European Commission 2002a: 60]. It does not say whether such a European identity consists of more than the answer to a simple question.

I intend here to consider the meaning of European identity underlying these varying standpoints and then take a closer look at the chances of a European identity being a real basis for Europe's further political development.

In my attempt to give an idea of what European identity is, I am following the concepts of collective identity that speak of a subject of identification, an object of identification, and a particular relationship between a subject and an object [Gerhards 2003]. In the discussion of the subject of identity I refer to the population of the 15 member states of the European Union. The object of identification is the European Union itself, and the relationship between subject and object consists in the people's feelings towards the European Union. It should be clear that any concept of collective identity is surely not to be understood as the physical identity of Europeans with the European Union, but rather as the cognitive identification of Europeans with the European Union. The first definition of European identity thus means a sense of closeness that unites European citizens with their spatial surroundings - here, the Europe of 15 member states.

However weak or strong this feeling may be, it cannot be taken as sufficient reassurance for political action as long as it is tied only to emotion. Feelings are subject to fluctuations and sometimes follow irrational developments. With respect to a historically young object of identification like the European Union, which is developing now alongside existing objects of identification (like the nation or a region), it is not possible to imply a distinctive emotional relationship. Especially during the current process of European integration, which is said to be in need of a European identity for its success, expressions of feelings or opinions are not enough to back and secure integration policies. The claim for European identity must apply to reliable and in a certain sense calculable support for the political process. European identity becomes more binding when the individual's relationship with Europe is connected with fulfilled - or disappointed - interests. Fulfilled expectations and interests support the growth of a sustainable identification with Europe, which can serve as a sound basis for the further development of the European project.

I should therefore complete the above-mentioned definition of collective identity towards Europe: If European identity is not to remain merely lip-service but is to be supportive to the European integration process, then the constitution of a European identity not only needs an emotional aspect but must also be completed with a utilitarian component. This means the European Union must become intensively and permanently tied to the interests of citizens. This link can result from the perception of the advantages people see in European Union membership. Or, it can be expressed through a willingness to support others in an attitude of solidarity. 
In this respect, for this study I am looking at the support for the further development of Europe. Consequently, support here means not only verbal approval but also transnational solidarity, i.e. support even if engagement in favour of the community of Europeans is not to be free of charge. ${ }^{1}$ The coming Eastern enlargement of the European Union sets a good opportunity to test the inherent sustainability of the support for Europe. Enlarging the Union by ten or twelve states will put some burden - at least a short-term one - on today's member states [Weise et al. 2001; Wernicke 2001]. If EU-Europeans support enlargement in spite of the expected costs, in terms of financial burdens, migration or labour-market problems, I will judge this as an indicator in favour of the development of a sustainable community of Europeans. As Georg Vobruba puts it: "Collective identities stand the practical test if they lead to acceptance of demands for redistribution" [Vobruba 2001: 127; my translation]. Thus the question is not only, in the words of Jürgen Habermas, whether "Swedes and Portuguese are willing to vouch for each other" [Habermas 2001: 101; my translation], but whether the solidarity of EU citizens would make Swedes and Portuguese vouch for Poles and Czechs, too.

My notion of European identity will not of course render the rather normative debate obsolete, but it will help to advance the discussion by adding the utilitarian aspect. I will begin the examination with an investigation of the support for enlargement of the European Union on two levels: on the level of political elites and on the level of citizens.

\section{The stance the EU governments are taking towards enlargement}

How are EU governments behaving in the run-up to enlargement? I shall present some contributions to the enlargement discussion and some of the strategies of political elites. As the following discussion will show, the positions I present here are typical ones. Therefore, I am not aiming at a complete documentation of all member countries, but rather concentrate on a few examples. I will start with the German position: the Minister of Foreign Affairs, Joschka Fischer, emphasises that the EU will not integrate petitioners but a "booming region, the dynamics of which all present members will profit from" [Fischer n.d.: 2; my translation]. In his view, Germany has a vital interest in realising the enlargement as quickly as possible because of the political and economic prospects [ibid.]. The German Ministry for Economic Affairs is also convinced that in the long run Germany will enjoy economic advantages from enlargement. "The enlargement puts Germany - and especially the new Bundesländer - more into the centre of the European Union. The enlargement will offer the German economy great prospects" [Bundesministerium für Wirtschaft und Technologie: 2002; my translation].

\footnotetext{
${ }^{1}$ It should be kept in mind that solidarity is not only an expression of feelings towards other humans, it also has a strong component of the pursuit of an interest [Nissen 1999].
} 
Similar statements are made in Austria. The President of the Austrian Republic, Thomas Klestil, points explicitly to the advantages of enlargement for the Austrian economy and the country's security policy: "Since the opening of the East in 1989 Austria in particular gained enormously from economic relations with Central and Eastern European countries. Leading these countries up to the EU puts Austria from the so far geographically marginalised position back to the centre of a unified Europe again" [Klestil 2002; my translation]. The same interpretation can be found in the documents of the ÖVP, the Austrian conservative party and the party of Chancellor Wolfgang Schüssel: "We Austrians in particular will, like the Germans, gain most from enlargement. The development of our trade balance, and the increases in export since the opening of the East clearly show this" [Stenzel 2002: 5; my translation].

The British government has mainly aimed at codifying the new political order that has emerged on the European continent since the fall of the Iron Curtain. Tony Blair demonstrated this, for example, in his speech on Europe's political future presented at the stock exchange in Warsaw: "Without enlargement, Western Europe will always be faced with the threat of instability, conflict and mass migration on its borders" [Blair 2000].

Blair's former FCO Minister for Europe, Peter Hain, additionally stressed that "our support for enlargement is not only based on our desire to reunite Europe after the divisions of the Cold War. It also derives from a hardheaded assessment of the benefits that enlargement will bring for the UK" [Hain 2001].

Contrary to these widely affirmative positions, French European politics seem to be guided mainly by a fear of the revitalisation of German predominance. At least this concern was expressed during the French presidency, when France was able to prevent Germany's revaluation in the European Council [Neunreither 2001: 190]. At the end of 2001, the former Minister of Foreign Affairs, Hubert Vedrine, tried to reduce the pace of the enlargement process by proposing to accept the applications from Romania and Bulgaria in the first enlargement round, too. This would clearly have postponed accession for all [Oldag 2001a]. In the same manner France protracted financial revisions and hindered reform efforts concerning the common agricultural policy. The required agreement between Germany and France could only be reached in October 2002, leaving less than two months to go before the EU had wanted to come to a final agreement with the candidate countries in the negotiations on the development of agricultural policy.

The governments of Southern European member states share the French position and worry about a realignment of power in the enlarged European Union. Those fears are especially strong in Spain and Portugal, but also in Italy. They are expressed in the demand for greater emphasis on Mediterranean politics and for non-impairment of vested rights [Weise et al. 2001: 130]. Former Italian Minister of Foreign Affairs, Lamberto Dini, pointed to the particular role of the EU members in the South: "It is up to Italy, more than any other country, to bring the Mediterranean back to the centre of Europe, to make it understood that no Europe would be complete not only without the East but also without the South" [Dini 2000]. Today, the 
Italian attitude does not seem to have become any more liberal with Silvio Berlusconi in power.

Spain's Prime Minister José Maria Aznar is leading the Southern European countries in their negotiations on the protection of acquired possessions. During recent years he has concentrated on securing the subsidies Spain receives from EU funds. His commitment to Spanish interests became particularly evident when Aznar was able to change the EU's budgeting to the benefit of his country during protracted meetings in Berlin in 1999. One year later, in Nice, he successfully bargained for Spain's share of votes in the European Council. In April 2001, he rocked the boat by hinting at the so-called statistical effect. Leaving all criteria for the distribution of subsidies unchanged after the accession of poorer countries would make Spain arithmetically 'richer' compared to the EU average and thus less entitled to receiving money from the structural and cohesion funds: "Spain thinks it is necessary to find a solution to this problem during the accession talks" [Aznar 2001]. At the same time, Spain's Prime Minister - partly assisted by the representatives of Greece, Portugal and Italy - blocked an agreement on freedom of movement for the labour force, which made the other member states accuse him of blackmail: "Madrid's claims resemble a package deal between enlargement and continued payment of subsidies" [Oldag 2001b; my translation].

Greece and Portugal, with varying intensity, have joined Spain in its strategy of protecting acquired possessions, but also follow their own paths. The Greek government supports enlargement, especially because of the accession of Cyprus, and it ties its vote to the consideration of Greek-Cyprian interests. With respect to the future distribution of funds, Greece doesn't have much to fear, as the country is even poorer than some of the candidate countries. Prime Minister Kostas Simitis stressed that Greece's "central minimum goals will always be: to ensure the equal participation of the country in the EU institutional system that will emerge and in particular in the inner core of the Union" and "to guarantee the necessary redistributive policies for cohesion and solidarity as well as the budget needed for the implementation of the policies. It is a matter of central importance that the social dimension of the Union be enhanced, that the European social model be reinforced and inter-regional and social inequalities be combated" [Simitis 2001: 11].

Former Portuguese Prime Minister Guterres offered an interesting point of view. In contrast to the political rationality that is usually shown, he pushed materialistic and short-sighted calculations into the background, while arguing in favour of enlargement. "We need a stable Europe that includes the East European countries. This is more important than EU funds for Portugal. I'd like to put it this way: It is in our own best - if you like: egoistic - interest to have a long-term stable Europe. This means we put short-term egoistic goals aside" [Guterres 1999; my translation]. In view of the country's economic problems, the Portuguese did not seem willing to follow Guterres' idea of postponing a rational short-term pursuit of interests in favour of national long-term interests. His Socialist Party lost the local elections in December 2001 in all major cities and Guterres resigned. 
I will leave this point with the above examples alluding to the national positions. Adding more quotes from more countries would not increase the amount of insight into the distribution of interests on the political level. It is not my intention to give a full overview of the positions on enlargement taken by the elites, but rather to demonstrate the basic North-South distinction regarding support for enlargement that divides the European Union in its present-day profile [Weise et al. 2001: 131]. Basically all members state themselves to be in favour of enlargement. But underneath this consensus, the Southern European countries receiving subsidies fear that in the course of enlargement the redistribution of funds from West to East will in fact be a redistribution from South to East. The Southern European countries expect they will have to stand aside for the benefit of the new recipients in the East [Vobruba 2003: 41].

\section{Citizens' opinions on European enlargement}

What do people in Europe think about enlargement? Do citizens, like politicians, support enlargement in principle but differ in detail? The answer is yes, but in a way other than expected.

Twice a year the European Commission publishes the Standard Eurobarometer, which contains the main results of public opinion surveys carried out in all member countries. Although some of the East European countries applied for membership as early as 1994, ${ }^{2}$ people in the EU were for the first time explicitly asked for a statement on enlargement in autumn 2000. In that survey - Eurobarometer 54 - an average of $44 \%$ of the respondents were in favour of enlargement and 35\% voted against it. By spring 2002 (Eurobarometer 57) the support for enlargement had increased to 50\%, while $30 \%$ were against it and $20 \%$ did not have an opinion (figure 1). ${ }^{3}$

These averages hide the substantial variations among the national results. Figures 2 to 5 show the distribution of advocates and sceptics in each member country over time.

Between autumn 2000 and autumn 2001, the highest approval of enlargement is expressed in Greece (figures 2 to 4). Only in spring 2002 were the Greeks surpassed by the Danish (figure 5). After Greece and Denmark, support is highest in Spain, Italy and Portugal, and also in Sweden and Ireland. In autumn 2001, approval rates shot up in all member states. In Greece the figure for those in favour of enlargement even reached $75 \% .{ }^{4}$ At the lower end of the scale there is a group of coun-

\footnotetext{
${ }^{2}$ Malta and Cyprus even applied for membership in 1990.

${ }^{3}$ Standard Eurobarometer 58 (autumn 2002) does not deal with enlargement issues but refers to the Flash Eurobarometer 132/2 on enlargement, released in December 2002. The latter of course has many questions on enlargement, but none that would contribute to elaborating figure 1 . See note 3 .

4 The European Commission itself assumed that a change in the question might have influenced the answers but has not given any further explanation about this question so far. With
} 
Figure 1. Support for Enlargement

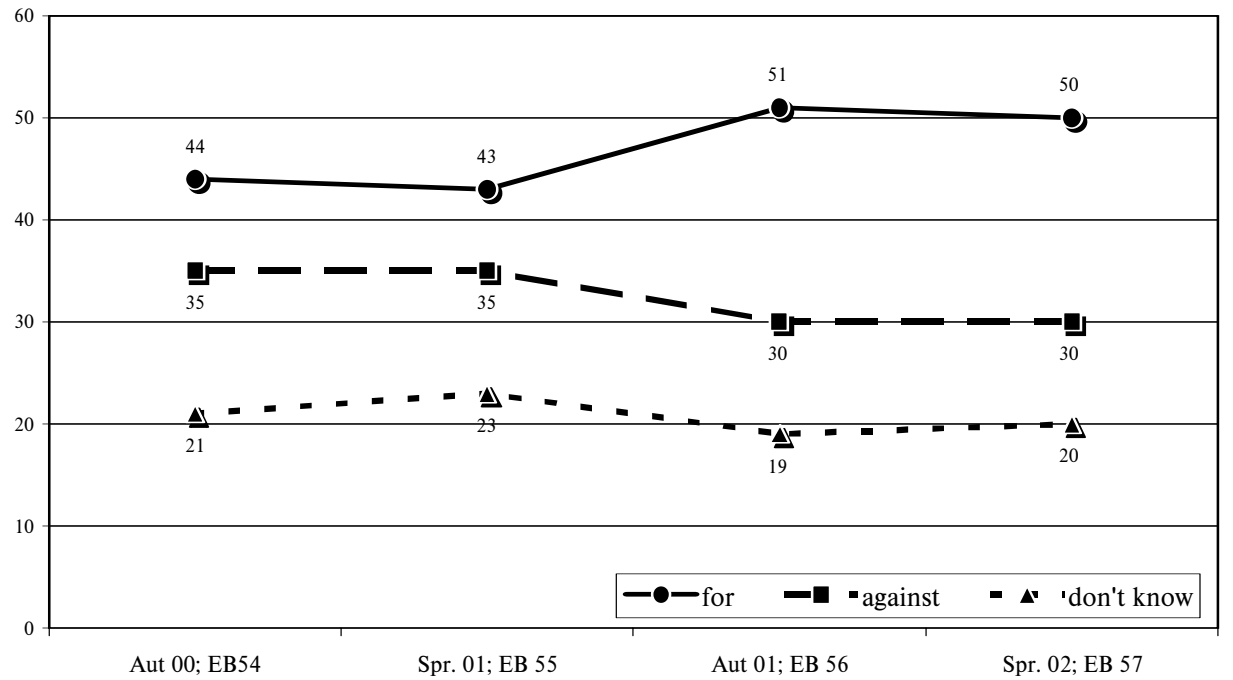

Source: European Commission Standard Eurobarometer (several years)

Figure 2. Enlargement - for or against? (autumn 2000)

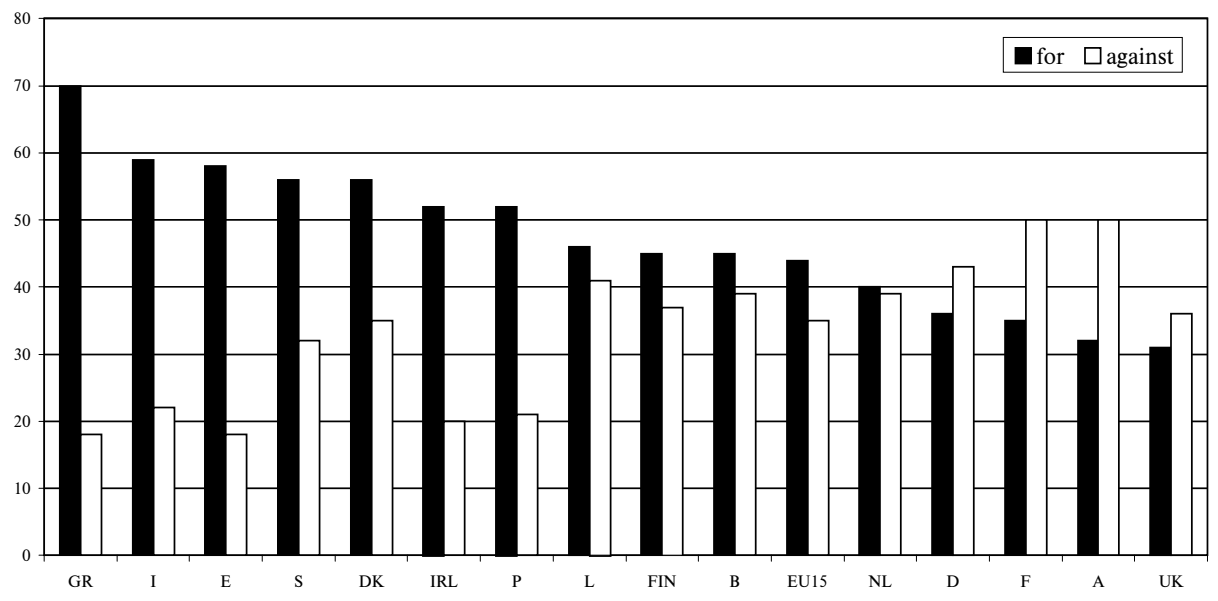

Source: European Commission Standard Eurobarometer 54, autumn 2000 
Figure 3. Enlargement - for or against? (autumn 2000)

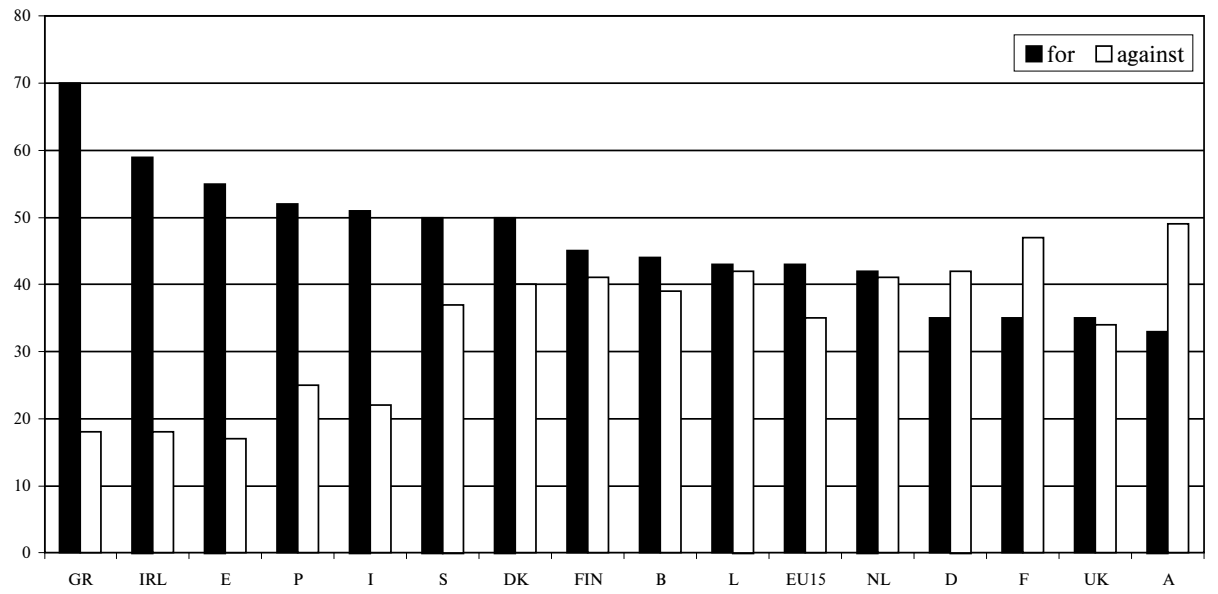

Source: European Commission Standard Eurobarometer 55, spring 2001

Figure 4. Enlargement - for or against? (autumn 2001)

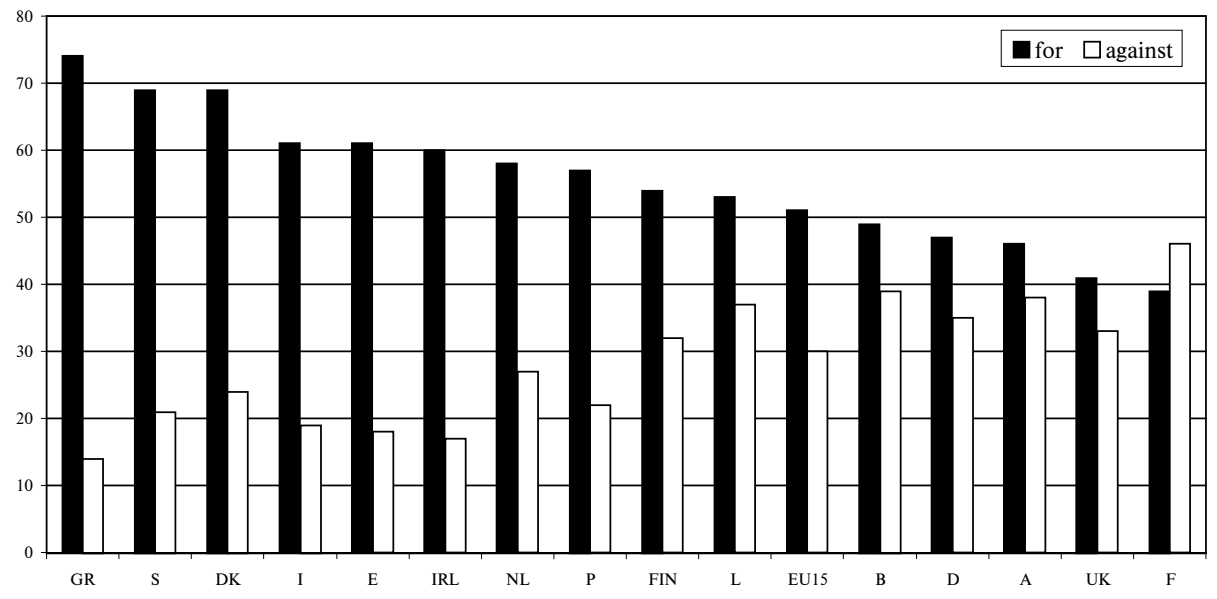

Source: European Commission Standard Eurobarometer 56, spring 2001 
Figure 5. Enlargement - for or against? (spring 2002)

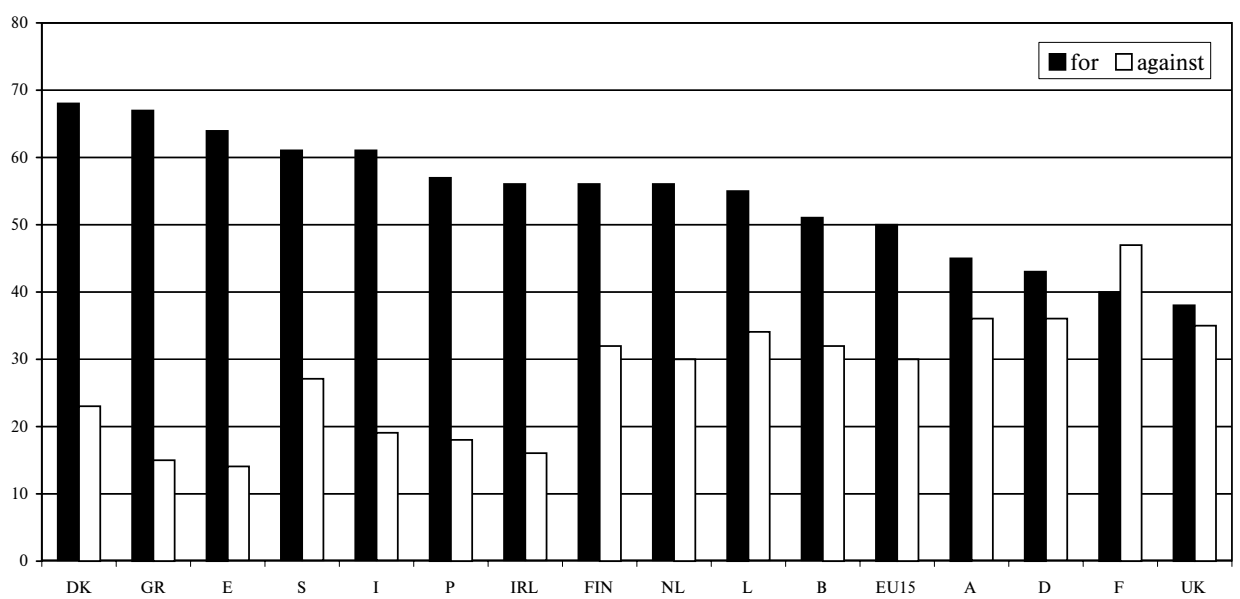

Source: European Commission Standard Eurobarometer 57, spring 2002

tries that is also stable through all four waves. Germany, France, Austria and the United Kingdom bring up the rear with the smallest share of advocates. The survey results from autumn 2000 and spring 2001 show that in each of these countries the proportion of those against enlargement was bigger than the proportion of those in favour of it (figures 2 and 3). This heavy scepticism has weakened since, and only in France do more people still reject enlargement than approve it (figure 5).

If we compare people's opinions with the statements of the political elites we can see a discrepancy that might have consequences for the political future of the European Union. In most of the current member states people do not share the interpretations given by their governments. The only exceptions are France and Greece - each for known historical and political reasons. In most of the other

the purpose of gathering information on the public opinion of enlargement, Standard Eurobarometer 54 and 55 asked the question: 'What is your opinion on the following statement? Please tell me whether you are for it or against it: The European Union should be enlarged and include new countries' [European Commission 2000]. The phrasing of this particular question has been slightly changed in Eurobarometer 56: '... the enlargement of the European Union to include new countries' [European Commission 2002a]. These questions could be answered with 'for', 'against' and 'don't know'. Question 2 of the latest Flash Eurobarometer 132/2 asks, 'Are you, personally, totally in favour, rather in favour, rather opposed or totally opposed to the enlargement of the European Union?' [European Commission 2002b], and allows for the categories 'totally in favour', 'rather in favour', 'rather opposed', 'totally opposed', 'it depends on the country/countries', 'don't know/no answer'. Obviously this question again breaks with the pattern and makes comparability with previous samples impossible. 
Figure 6. Exemplary positions towards enlargement

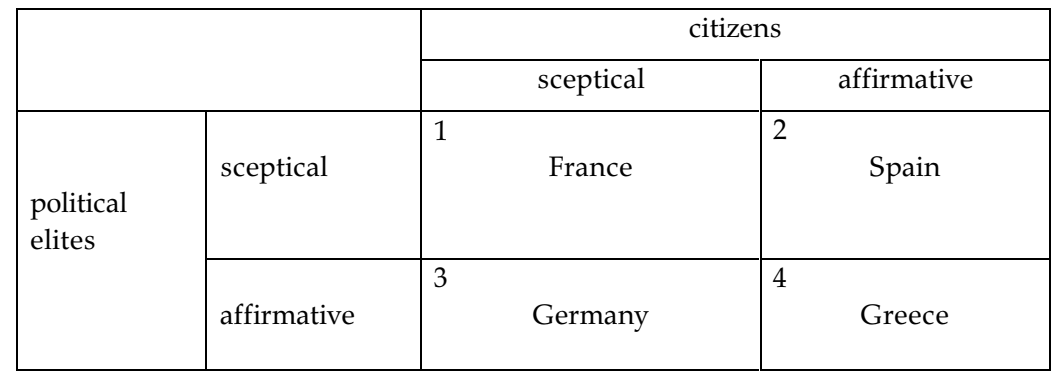

EU countries it is necessary to note that the interpretations of citizens and elites differ. ${ }^{5}$ The table above presents a starting point for further discussion in summarising the possible constellations of citizens' and elites' opinions in four typical cases (figure 6).

According to the information in the Eurobarometer, it may be assumed that not only the political actors but also EU citizens know that enlargement will not be without its costs. Interestingly, it is particularly the people in the Southern European countries, who are highly in favour of enlargement, who also prove to be remarkably aware of the costs. The same survey in autumn 2000 that showed $70 \%$ of Greek citizens supporting enlargement also indicated that the same share of respondents expressed fears over job relocations, while $79 \%$ were afraid of disadvantages for farmers, and more than half of the Greek population said enlargement would become too expensive. Even so, two-thirds of the Spanish population and three-quarters of the Portuguese feared the onset of problems for agriculture. In both countries, more than $60 \%$ of respondents expect that the amount of EU subsidies will decrease [European Commission 2000]. In Flash Eurobarometer 132/2, not only the sceptics like Germans and Austrians, but also - and even more strongly the major advocates like the Spanish and the Portuguese featured the highest (and a generally increasing) ratio of respondents that believe enlargement will lead to a rise in unemployment [European Commission 2002b]. This means that the knowledge of problems that might arise with enlargement does not necessarily lead respondents to reject the accession of East European countries to the European Union.

${ }_{5}^{5}$ In a different but related context the Swedes recently gave proof of the differing perceptions when the refendum on the Euro failed in September 2003. 


\section{The problematic distributions of advocates and sceptics}

I have characterised the visible readiness that exists to accept redistribution to one's own debit in order to promote the European project as an indicator of the development of a sustainable European identity. In this respect, the data on cost-consciousness in countries like Greece or Spain could lead us to think that there is a growing collective identity of Europeans. Perhaps this observation is correct. But, on the other hand, only half of all EU citizens show some readiness to invest in enlargement, and in four countries the number of those who are sceptical towards or undecided about enlargement still exceeds the number of advocates, which means that we can hardly speak of a sustainable collective identity. In this heterogeneous atmosphere, with a widespread proportion of sceptics, politicians cannot rely on support for enlargement.

This deficiency could get the enlargement process into trouble, as the political elites and institutions need the support of the population in order to successfully bring off the accessions. According to the Amsterdam Treaty on the European Union, the decision to enlarge the EU has to be ratified by every single member state: "The conditions of admission and the adjustments to the Treaties on which the Union is founded which such admission entails shall be the subject of an agreement between the Member States and the applicant State. This agreement shall be submitted for ratification by all the contracting States in accordance with their respective constitutional requirements" [European Commission n.d.]. Constitutional requirements can mean that member countries ratify important European decisions concerning enlargement through national referenda. This holds true not only for the accession treaties but also for the European Constitution presented by the EU convent, which will replace all previous agreements. The Danish Constitution, for example, requires a referendum whenever national sovereignty is transferred to transnational authorities, as does the Irish Constitution with respect to international agreements. According to the EU Directorate General for Enlargement, at present no member state plans to hold a referendum on the accession treaties. But in 13 out of 15 member states national referenda are constitutionally possible, and in 9 countries the outcome of a referendum is binding [Stoiber and Thurner 2000]. In most of the countries, the holding of a referendum depends on the initiative of institutional actors. Consequently, governments or parliaments can prevent a plebiscite. Still, it is not out of the question that a particular public-political climate could render it necessary to sanction the accession treaties through a national referendum in one member country or the other. If in this case the people did not share the opinion of the elites the process of Eastern enlargement could be interrupted. ${ }^{6}$

In order to avoid such a threat, political actors on the EU level and in member countries could try to make strategic use of those results from the Eurobarometer

\footnotetext{
${ }^{6}$ The same holds true, of course, for all referenda to be held in the candidate countries. But the impact of these referenda is not the issue here.
} 
surveys that indicate a positive attitude towards enlargement and could try to raise general attention for the numerous enlargement advocates. But, in fact, the impressing data from Greece, Spain or Sweden can hardly be used to convince the sceptics. Whoever wants to argue for enlargement by presenting affirmative majorities cannot hide the equally strong groups of waverers. One heading from a German newspaper perfectly illustrates the inherent dilemma: "One in two in favour of EU enlargement" (Süddeutsche Zeitung, October 22, 2002). With an approval rate of $50 \%$, it follows conclusively that every second person is likewise undecided or explicitly not in favour of enlargement.

Using the 2x2-matrix from above (figure 6) I will briefly discuss how the Eurobarometer results could be capable of getting the political actors into trouble. Countries in which both the citizens and the political elites have reservations towards EU enlargement can obviously not be used to promote enlargement (cell 1). These countries are themselves in a comparatively favourable situation, as there is a national consensus over the fact that approval is only given if the national situation does not deteriorate through enlargement. There is little interest in propagating the approving majorities elsewhere. At the moment, France seems to be the only EU member state in this constellation.

Sceptical elites with an affirmative population must be hesitant about drawing attention to the public opinion in their country (cell 2) because then their particular strategy would quite likely become the focus of international criticism: Why, for example, does the Spanish government act reservedly while the Spanish people are definitely in favour of enlargement? At the same time, sceptical elites cannot attempt to reverse the positive mood among their citizenry. With an atmosphere in Europe that is basically pro-enlargement there is no way of starting a publicity campaign against it.

The political elites who explicitly support Eastern enlargement can encounter some difficulties with the population majorities that are sceptical towards this issue (cell 3). Public opinion in such countries is neither a good advertisement in favour of enlargement nor suitable evidence that politicians are acting in accordance with the preferences of the people. Every citizen could conclude from the distribution of enlargement sceptics and advocates that political elites are acting against the will of the majority. At the same time, political actors would have to ask themselves why they are pushing enlargement forward in opposition to the majority in their country. Making references to majorities elsewhere would not solve the problem. On the contrary, this could give rise to defiance and opposition among sceptical and undecided citizens and could in general sharpen the awareness of the sceptics' motives.

Finally, countries where elites and people both show approval for enlargement are politically best off (cell 4). But, as Greece and Portugal demonstrate, the road to enlargement is primarily a strategic game. Whoever for the good of the whole argues with the overwhelming pro-enlargement majorities in their own country runs the risk of having the other EU partners take this for a willingness to pay the costs. For tactical reasons Greece and Portugal, and also other member states, may come to 
the point where they link their political support to nationally oriented conditions, put forward a package deal, and finally come to act with reserve towards enlargement.

\section{Eastern enlargement as the project of elites}

These developments might not be very likely, but the thread of the arguments should give rise to a substantial discussion of credible political strategies. In the light of this constellation of problems, the limited reaction of politicians to the survey results is not surprising. Instead of promoting the currently established affirmative majorities from country to country, political actors are banking on getting more information about accession in order to increase support and think it especially important to clearly explain the enlargement process to the citizens of the EU and the accession countries [Verheugen n.d.: 26]. But information campaigns bind the rhetoric of identity to rational cost-benefit analysis. The more financial questions come to the core of the negotiations, the more clearly the burden expected from enlargement is put in figures, and the more important the reference to national advantages seems to be, the more the importance of cost-benefit-analysis will exceed the effect of political rhetoric. As long as the EU tries to keep negotiations with candidate countries behind closed doors, as long as enlargement remains the task of some diplomats and civil servants in Brussels, and as long as high-rank member state officials only meet to defend national priorities [Höltschi 2001], the credibility of enlargement rhetoric will remain under pressure and the readiness for redistribution is likely to go down. The rhetoric of collective identity may be understood as nothing more than rhetoric, and it may be put aside while calculating benefits will prevail.

Appealing to the idea of a European family can hardly conceal solid conflicts of interest. Particularly the financial controversies among the EU member states and between EU and candidate countries tend to leak out despite the closed doors, and they are capable of undermining the political rhetoric primarily for two reasons: First, the running conflicts over the distribution of enlargement burdens between the Northern European net payers and the Southern European net beneficiaries are a visible contradiction to the call for a growing community of all Europeans. So far the problem of financial burden-sharing that arose during each of the previous enlargement rounds was solved simply by increasing the existing funds or inventing new funds in order to obtain approval from those member states that were likely to experience disadvantages through enlargement [Emmerling n.d.]. This is not a viable solution today because the member states cannot see sufficient financial options open to increase the budget in order to compensate anybody for losses. Thus, bargaining for national advantages forces its way to the surface again and again during the European summits and the Council of Ministers negotiations. ${ }^{7}$

\footnotetext{
7 The compromise recently found between France and Germany concerning Common Agricultural Policy does not really break with this logic. The deal only postponed the argument
} 
Second, the negotiations between the European Union and the candidate states show that EU political elites tend to measure with two yardsticks when assessing situations. The acquis communautaire requires East European countries to achieve standards which in some cases, like the treatment of refugees and minorities or ecological requirements, even some EU member states do not yet fulfil. In developing the common market the EU is eager to ensure that the market access of the new members does not worsen the conditions for the old member states. This attitude must create an impression among the candidate countries that they are being fleeced until they also become members of the European Union. Consequently, polls in the candidate countries have shown sinking enthusiasm for accession, and the wariness about Europe is spreading. Public opinion polls in Latvia, Estonia and Malta resulted in less than $50 \%$ of the polled saying they would vote for EU membership in a coming referendum [European Commission 2002c: 57]. ${ }^{8}$ The strategies the political elites adopt to safeguard national or EU interests at the expense of others do not serve to strengthen public support for enlargement, and consequently nor do they serve the development of a sustainable European identity.

\section{Conclusion}

In this article I have attempted to provide stimulus to the discussion of the meaning and relevance of collective identity in the process of European integration. I tried to draw some attention to the fact that national and EU politicians are still pursuing enlargement as a project of the elites. Although there is a significant share of enlargement advocates among European citizens, the European Commission's survey results can hardly be adopted as a means to integrate all of Europe's public in the enlargement process. It seems too difficult to isolate the approval amidst the variety of public opinions and thereby use it to enhance the enlargement process. Consequently, political elites do not pay sufficient attention to the high level of consent that exists in some countries and do not use these favourable attitudes to the benefit of Europe's common future. Instead, they rely on a mixture of rhetoric about identity and rational cost-benefit calculations.

Although my findings are preliminary and need further examination, there is some evidence that European identity, as perceived in the Eurobarometer, is not sufficient as a reliable basis for Europe's future development. Instead, the orientation towards national interests may triumph over the feeling of European identity. This, of course, does not mean that Eastern enlargement of the European Union is doomed to fail. However, it does follow that political elites in their reference to a collective European identity and disengagement from public opinion undermine pub-

about the distribution of financial burdens and is rather an agreement not to prevent the successful conclusion of the accession talks than a solution to CAP problems.

${ }^{8}$ In spite of these unfavourable tendencies in all the candidate countries the majority citizens could be convinced to vote for accession in the national referenda. 
lic support for enlargement. Politicians may as a result seriously endanger an enlargement process that needs extraordinary public approval, and worsen the chances for the development of collective identity in Europe, which are not too good anyway.

SYLKE NISSEN teaches sociology and political sciences at the universities of Frankfurt/Main and Leipzig. She is co-editor of the journal Soziologie. Her recent publications include Kriminalität und Sicherheitspolitik (ed., Leske $\mathcal{E}$ Budrich Verlag 2003) and Die regierbare Stadt (Westdeutscher Verlag 2002).

\section{References}

Aznar, José Maria. 2001. Memorandum Regionale Politik und Erweiterung. online: http://www.info-spanischebotschaft.de/doku/r4htm

Blair, Tony. 2000. Prime Minister's Speech to the Polish Stock Exchange in Warsaw. October 6, 2000. online: http://www.number-10.gov.uk/output/page2373.asp

Bundesministerium für Wirtschaft und Technologie. 2002. Förderung der Grenzregionen zu den Beitrittsländern. Berlin: BMWT.

Dini, Lamberto. 2000. Speech by the Minister for Foreign Affairs, the Rt. Hon. Lamberto Dini, at the Canova Club on the Process of European Union Enlargement. online: http://www.esteri.it/eng/archives/arch_press/speeches

Emmerling, Thea. n.d. Von der Strukturpolitik zum europäischen Finanzausgleich? München: Centrum für angewandte Politikforschung. online: http://www.cap.uni-muenchen.de/download/2002_emmerling.pdf

European Commission. 2000. Standard Eurobarometer 54, Autumn 2000. online: http://europa.eu.int/comm/public_opinion/standard_en.htm

European Commission. 2002a. Standard Eurobarometer 57, Spring 2002. online: http://europa.eu.int/comm/public_opinion/standard_en.htm

European Commission. 2002b. Flash Eurobarometer 132/2 "Enlargement of the European Union." online: http://europa.eu.int/comm/public_opinion

European Commission. 2002c. Candidate Countries Eurobarometer 2001. online: http://europa.eu.int/comm/public_opinion

European Commission. n.d. Treaty on European Union, consolidated version, signed at Amsterdam on 2 October 1997. online: http://europa.eu.int/eur-lex/en/treaties/dat/treaties_en.pdf

Fischer, Joschka. n.d. "Vorwort." In Die Europäische Union - Fragen zur Erweiterung. Auswärtiges Amt. Berlin: BMA.

Gerhards, Jürgen. 2003. "Identifikation mit Europa. Einige begriffliche Vorklärungen." In Entstaatlichung und soziale Sicherheit. Verhandlungen des 31. Kongresses der Deutschen Gesellschaft für Soziologie in Leipzig 2002, edited by Jutta Allmendinger. Opladen: Leske \& Budrich (in press).

Guterres, Antonio. 1999. “Die Osterweiterung ist der Schlüssel für ein stabiles Europa." Die WELT, July 23, 1999.

Habermas, Jürgen. 2001. Zeit der Übergänge. Frankfurt/Main: Suhrkamp.

Hain, Peter. 2001. "The Benefits of Enlargement." Speech by FCO Minister for Europe, Peter Hain. July 24, 2001. online: http://www.fco.gov.uk 
Höltschi, René. 2001. "Europäer werden dagegen sehr..." Neue Zürcher Zeitung, NZZ-Folio: Europa - Schwieriger Weg zur Einheit. No. 9, September 2001. online: http://wwwx.nzz.ch/folio/archiv/2001/09/articles/hoeltschi.html

Klestil, Thomas. 2002. "Veto würde dem Geist der Einigung Europas widersprechen." Focus Europa 1/2002. online: http://www.idm.at/publikationen/focus.htm

Münch, Richard. 1999. "Europäische Identitätsbildung." Pp. 223-252 in Kultur, Identität, Europa, edited by Reinhold Viehoff and Rien T. Segers. Frankfurt/Main: Suhrkamp.

Neunreither, Karlheinz. 2001. "The European Union in Nice: A Minimalist Approach to a Historic Challenge." Government and Opposition: 184-208.

Nissen, Sylke. 1999. "Zu den Entstehungs- und Geltungsbedingungen von Solidarität." In Ethik und Sozialwissenschaften, no. 7: 224-226.

Oldag, Andreas. 2001a. "Die EU-Erweiterung gerät ins Stocken." Süddeutsche Zeitung, December 11, 2001.

Oldag, Andreas. 2001b. "Auf Euro-Entzug." Süddeutsche Zeitung, May 15, 2001.

Simitis, Kostas. 2001. Speech by Kostas Simitis, Greek Prime Minister, at the event "The Future of the European Union and Greece" organised by the EKEM. July 11, 2001. online: http://europa.eu.int/futurum/congov_en.htm

Stenzel, Ursula. 2002. "EU-Erweiterung als Jahrhundertprojekt: Im Interesse Österreichs." In Die Erweiterung der Europäischen Union aus Sicht der ÖVP-Delegation im Europäischen Parlament. Die ÖVP-Delegation im Europäischen Parlament. Brüssel: ÖVP.

Stoiber, Michael and Paul W. Thurner. 2000. Der Vergleich von Ratifikationsstrukturen der EU-Mitgliedsländer für Intergouvernementale Verträge: Eine Anwendung des Veto-Spie-ler Konzeptes. online: http://www.mzes.uni-mannheim.de/publications/wp/wp-27.pdf

Verheugen, Günther. n.d. "Stabilität und Frieden in Europa sichern." P. 3 in Die Europäische Union - Fragen zur Erweiterung. Auswärtiges Amt. Berlin: BMA.

Vobruba, Georg. 2001. Integration + Erweiterung. Wien: Passagen Verlag.

Vobruba, Georg. 2003. "The Enlargement Crisis of the European Union: Limits of the Dialectics of Integration and Expansion." Journal of European Social Policy 13 (1): 35-49.

Weise, Christian, Martin Banse, Wolfgang Bode, Barbara Lippert, Ferdinand Nölle and Stefan Tangermann. 2001. Reformbedarf bei den EU-Politiken im Zuge der Osterweiterung der EU. Berlin: Deutsches Institut für Wirtschaftsforschung.

Wernicke, Christian. 2001. 'Die Armen gegen die Ärmsten'. Die ZEIT, no. 37. 